\title{
Estimation of The Physico-Chemical Parameters in Marine Environment (Yumurtalik Bight- Iskenderun Bay)
}

\author{
Gökhan Tamer Kayaalp ${ }^{1}$, Oya Ișık² ${ }^{2}$ Benin Toklu Alıçlı ${ }^{3}$ \\ ${ }^{1}$ Department of Animal Science, Agriculture Faculty, Çukurova University, 01330 Adana, Turkey \\ ${ }^{2}$ Department of Basic Sciences, Faculty of Fisheries, Çukurova University, 01330 Adana, Turkey \\ ${ }^{3}$ Department of Biology, Faculty of Science, Istanbul University, 34134 Vezneciler/İstanbul, Turkey \\ A R T I C L E I N F O \\ Article history: \\ Received 12 December 2015 \\ Accepted 31 December 2015 \\ Available online, ISSN: 2148-127X \\ Keywords. \\ Environmental parameters \\ Determination Coefficient \\ Regression model \\ Yumurtalik Bight \\ * Corresponding Author: \\ E-mail: tkayaalp@cu.edu.tr

A B S T R A C T \\ The study was carried out to estimate the temperature, light intensity, salinity, Dissolved \\ $\mathrm{O}_{2}$ (DO), $\mathrm{pH}$ values and the biotic parameter chlorophyll- $a$ in the water column related \\ with the depth. Because, the physico-chemical parameters affect greatly both primary and \\ secondary producers in marine life. For this purpose the physico-chemical properties \\ were determined day and night for 40 meter depth during the eight days. The means were \\ compared by using the analysis of variance method and Duncan's Multiple Comparison \\ Test. Also physico-chemical parameters were estimated by using the analysis of \\ regression and correlation. The effect of temperature and salinity were found significant \\ according to the result of the analysis of variance during the day. Also the similar results \\ were found for the night. While the effect of the depth on the chloropyll- $a$ a was \\ significant in the night, the effect of the depth on the DO was not significant in the day \\ and night. The correlations among the depth and the parameters were defined. It was \\ found the negative correlation between the depth and the temperature and light intensity. \\ Determination coefficient of the model for salinity was also found different for day time. \\ The correlation values among the depth and the temperature, salinity and $\mathrm{pH}$ were found \\ different for the night.
}

\section{Introduction}

Biotic and abiotic interactions are associated with the living organisms in the water. The abiotic factors are important to understand the variation in diel? Vertical migration of the planktonic organisms, especially zooplankton. It is known that the primer productivity is affected from the environmental factors such as, temperature, light intensity, salinity, Dissolved $\mathrm{O}_{2}$ (DO) and, $\mathrm{pH}$. The hydrographical and hydrochemical properties are important to clarify the phytoplankton and zooplankton migrations and abundance at the different depths of the water column. The data related with the food chain in the marine environment can help to carry out the fisheries activities in coastal waters, effectively. The studies have been carried out in the region about the hydrographical and hydrochemical properties of the region and the effect of the physico-chemical factors on the phytoplankton abundance and seasonal distribution of protozooplankton (Akyuz, 1957; İyiduvar, 1986; Avşar and Çiçek, 1999).

The objective of this study was to estimate the temperature, light intensity, salinity, $\mathrm{DO}, \mathrm{pH}$ values and the chlorophyll- acontent at the different depths of the water column for day and night in Yumurtalik Bight, Iskenderun Bay, north-eastern Mediterranean, Turkey in July.

\section{Material and Methods}

The study was carried out between 1-8 July in 2004 . The measurements were performed at the depths of 0 10,10-20,20-30,30-40 meters in Yumurtalik Bight (Iskenderun Bay, 36 $42^{\prime} 348 \mathrm{~N}, 35^{\circ} 46^{\prime} 330 \mathrm{E}$ ), northeastern Mediterranean, Turkey. Temperature, light intensity, DO, salinity and $\mathrm{pH}$ were measured daily with the YSI 650 model CTD around mid-day (12:00 am) and mid-night $(24: 00 \mathrm{pm})$ at the station determined by GPS (Garmin GPS12 model)

Phytoplankton abundance was connected with chlorophyll $a$ concentration $\left(\mu \mathrm{g} \mathrm{L}^{-1}\right)$. Water samples were taken from the five depths by Nansen bottles. Two litres of water samples were filtered through glass-fibber filter papers (Whatman GF/C) for the chlorophyll $a$ (chl $a$ ) measurements. Concentrations were determined by a UVVIS SHIMADZU-1240 Spectrophotometer after extraction in $90 \%$ acetone and held at $4{ }^{\circ} \mathrm{C}$ for $24 \mathrm{~h}$ in the darkness. The chl $a$ amount was calculated from the following equation,

$$
\begin{aligned}
& \mathrm{Ca}=11.6 . \mathrm{D}_{665}-1.31 \mathrm{D}_{645}-0.14 \mathrm{D}_{630} \\
& \mathrm{Chl} a\left(\mu \mathrm{g} \mathrm{L}^{-1}\right)=\mathrm{Chl} a . \mathrm{V} / \mathrm{V} .1
\end{aligned}
$$

Where,

$\mathrm{V}$ : Volume of water filtered for extraction 
$\mathrm{v}$ : Volume of acetone used

1: pathlenght (in cm) of cuvette (Parsons, et al., 1963).

The analysis of variance method and Duncan's Multiple Comparison Test were used to compare the means (Gill, 1955). The regression and correlation methods were used to determine the relationship between the depth and the physico-chemical factors (Draper, 1966).

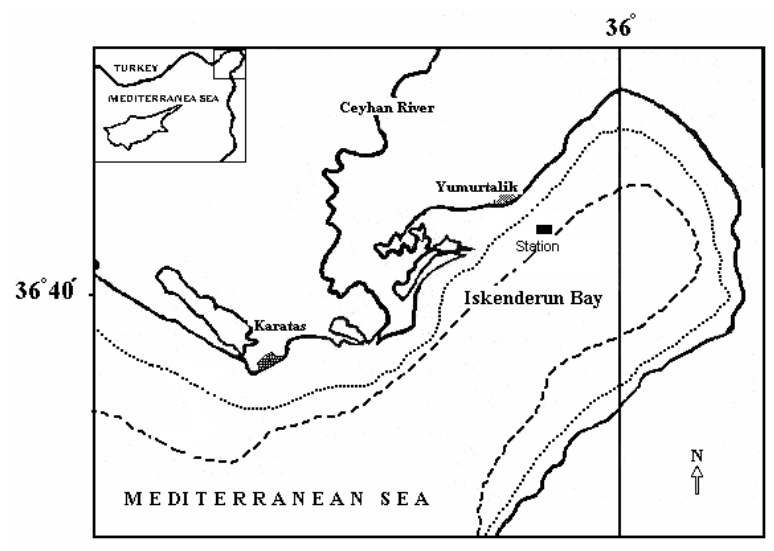

Figure 1 Sampling Station in Yumurtalik Bight

\section{Results}

The highest temperature at the surface water was recorded around the midday hours. The temperature was decreased by increasing of the depth. The lowest temperature was measured at the depth of $40 \mathrm{~m}$. The salinity was also changed by the depth during the day according to the result of the analysis of the variance $(\mathrm{P}<0.05)$ (Table 1, 2, 3).

The effect of the depth on the temperature and salinity was also significant statistically during the night $(\mathrm{P}<0.05)$ (Table 4,5 ). The temperature was decreased by increasing of the depth.

The salinity valuesin 20,30 and $40 \mathrm{~m}$ depths were found higher than surface and $10 \mathrm{~m}$ depth of the water. The dissolved oxygen values determined for different depths were similar during the day and night $(\mathrm{P}>0.05)$. The effect of the depth on the chlorophyll $a$ was found significant statistically for the night $(\mathrm{P}<0.05)$ (Table 5). The highest chlorophyll- $a$ value was observed at the depth of the 40 meter in the night. The chlorophyll- $a$ amounts of the other depths were found similar.

The correlation among the parameters and the depth were determined for day time data. While the negative correlation was found between the depth and the temperature and depth and the light intensity $(\mathrm{P}<0.01)$, the positive correlation was found between the depth and the salinity during the day. The temperature and light intensity decreased with the increasing of the depth. $(\mathrm{P}<0.05)$ (Table 6).

The regression model of the depth and temperature was estimated for the day values as Temperature $=28.464$ $-(0.896)$ depth.
Table 1 The effect of the depth on the temperature of the seawater in the day.

\begin{tabular}{l|c}
\hline \multicolumn{1}{c|}{ Depth } & Temperature \\
\hline $40 \mathrm{~m}$ & $23.7^{\mathrm{a}}$ \\
$30 \mathrm{~m}$ & $24.9^{\mathrm{b}}$ \\
$20 \mathrm{~m}$ & $26.2^{\mathrm{c}}$ \\
$10 \mathrm{~m}$ & $26.8^{\mathrm{d}}$ \\
Surface & $27.3^{\mathrm{e}}$ \\
\hline
\end{tabular}

The different letters in the same row denote significant differences $(\mathrm{P}<0.05)$.

Table 2 The effect of the depth on the salinity of the seawater in the day.

\begin{tabular}{l|c}
\hline \multicolumn{1}{c|}{ Depth } & Temperature \\
\hline Surface & $38.2^{\mathrm{a}}$ \\
$10 \mathrm{~m}$ & $38.3^{\mathrm{ab}} 38.5$ \\
$20 \mathrm{~m}$ & $38.3^{\mathrm{ab}} 38.5$ \\
$30 \mathrm{~m}$ & $38.7^{\mathrm{b}}$ \\
$40 \mathrm{~m}$ & $38.7^{\mathrm{b}}$ \\
\hline
\end{tabular}

The different letters in the same row denote significant differences $(\mathrm{P}<0.05)$.

Table 3 The effect of the depth on the temperature of the water in the night.

\begin{tabular}{l|c}
\hline \multicolumn{1}{c|}{ Depth } & Temperature \\
\hline $40 \mathrm{~m}$ & $23.2^{\mathrm{a}}$ \\
$30 \mathrm{~m}$ & $24.6^{\mathrm{b}}$ \\
$20 \mathrm{~m}$ & $25.7^{\mathrm{c}}$ \\
$10 \mathrm{~m}$ & $26.9^{\mathrm{d}}$ \\
Surface & $26.9^{\mathrm{d}}$ \\
\hline
\end{tabular}

The different letters in the same row denote significant differences $(\mathrm{P}<0.05)$.

Table 4 The effect of the depth on the salinity of the seawater in the night.

\begin{tabular}{l|c}
\hline \multicolumn{1}{c|}{ Depth } & Temperature \\
\hline Surface & $38.2^{\mathrm{a}}$ \\
$10 \mathrm{~m}$ & $38.5^{\mathrm{b}}$ \\
$20 \mathrm{~m}$ & $38.7^{\mathrm{c}}$ \\
$30 \mathrm{~m}$ & $38.7^{\mathrm{c}}$ \\
$40 \mathrm{~m}$ & $38.7^{\mathrm{c}}$ \\
\hline
\end{tabular}

The different letters in the same row denote significant differences $(\mathrm{P}<0.05)$.

Table 5 The effect of the depth on the chlorophyll $a$ in the night.

\begin{tabular}{l|c}
\hline \multicolumn{1}{c|}{ Depth } & Temperature \\
\hline $20 \mathrm{~m}$ & $0.26^{\mathrm{a}}$ \\
$30 \mathrm{~m}$ & $0.27^{\mathrm{a}}$ \\
$10 \mathrm{~m}$ & $0.31^{\mathrm{a}}$ \\
Surface & $0.34^{\mathrm{a}}$ \\
$40 \mathrm{~m}$ & $0.51^{\mathrm{b}}$ \\
\hline
\end{tabular}

The different letters in the same row denote significant differences $(\mathrm{P}<0.05)$.

The parameters in the regression model were found significant statistically so the regression model was found significant $(\mathrm{P}<0.01)$ Determination coefficient $\left(\mathrm{R}^{2}\right)$ of the model was calculated as 0.854 . While the temperature of 
the surface water is $28.464^{\circ} \mathrm{C}$ in the day, it is expected that the temperature decrease $0.896^{\circ} \mathrm{C}$ for each 1 meter increased.

The regression model of the depth and light intensity was estimated for the day values as:

$$
\text { Light }=1106.431-(241.346) \text {. Depth }
$$

The parameters in the regression model were found significant statistically so the regression model was found significant $(\mathrm{p}<0.01)$. Determination coefficient $\left(\mathrm{R}^{2}\right)$ of the model was calculated as 0.581 . While the light intensity of the surface water is $1106.431 \mu \mathrm{mol} \mathrm{m} \mathrm{s}^{-1}$ in the day, it is expected that the light intensity decrease $241.346 \mu \mathrm{mol}$ $\mathrm{m}^{2} \mathrm{~s}^{-1}$ for each 1 meter increased.

The regression model of the depth and salinity was estimated for the day values as:

$$
\text { Salinity }=38.107+(0.128) \text {. Depth }
$$

The parameters in the regression model were found significant statistically so the regression model was found significant $(\mathrm{p}<0.01)$. Determination coefficient of $\left(\mathrm{R}^{2}\right)$ the model was calculated as 0.208 . While the salinity of the surface water is $38.107 \mathrm{ppt}$ in the day, it is expected that the salinity increased $0.128 \mathrm{ppt}$ for each 1 meter increased.

The correlation value among the $\mathrm{pH}$, chlorophyll- $a$, DO and the depth weren't significant and the regression models weren't estimated for the parameters for day time. This situation was shown in Table 6.

The correlation among the parameters and the depth were determined for the night time data. While the correlation among the depth and the temperature, salinity and $\mathrm{pH}$ were found significant $(\mathrm{P}<0.01)$, among the $\mathrm{DO}$ and chlorophyll $a$ were found insignificant $(\mathrm{pP}>0.05)$. The regression models weren't estimated for DO and chlorophyll $a$ since the correlation values were low. The negative correlation between the depth and the temperature and the depth and $\mathrm{pH}$ was found during the night $(\mathrm{P}<0.01)$. The temperature and $\mathrm{pH}$ levels decreased with the increasing of the depth $(\mathrm{P}<0.05)$ (Table 7).

The correlation among the parameters (depth, temperature, salinity, $\mathrm{pH}, \mathrm{DO}$ and chlorophyll a) were shown in the Table 7.

The regression model of the depth and the temperature was estimated for the night values as:

$$
\text { Temperature }=28.405-(0.958) \text {. Depth }
$$

The parameters in the regression model were found significant statistically so the regression model was found significant $(\mathrm{P}<0.01)$. The determination coefficient $\left(\mathrm{R}^{2}\right)$ of the model was calculated as 0.84 . While the temperature of the surface water is $28.405^{\circ} \mathrm{C}$ in the night it is expected that the temperature decrease $0.958^{\circ} \mathrm{C}$ for each 1 meter increased.

The regression model of the depth and $\mathrm{pH}$ was estimated for the night as:

$$
\text { pH }=7.12-(0.006) \text {. Depth }
$$

Table 6 The correlation among the depth, temperature, salinity, pH, DO and chlorophyll $a$ in the day

\begin{tabular}{l|c}
\hline & Depth \\
\hline Depth & 1 \\
Temperature & $-0.924^{* *}$ \\
Salinity & $0.456^{* *}$ \\
pH & -0.189 \\
DO & -0.216 \\
Light & $-0.762^{* *}$ \\
Chl a & 0.235 \\
\hline **: $\mathrm{P}<0.01 ; *: \mathrm{P}<0.05$
\end{tabular}

Table 7 The correlation among the depth, temperature, salinity, pH, DO and chlorophyll $a$ in the night

\begin{tabular}{l|c}
\hline & Depth \\
\hline Depth & 1 \\
Temperature & $-0.916^{* *}$ \\
Salinity & $0.652^{* *}$ \\
pH & $-0.377^{*}$ \\
DO & -0.118 \\
Chl a & 0.206 \\
\hline
\end{tabular}

**: $\mathrm{P}<0.01 ; *: \mathrm{P}<0.05$

The parameters in the regression model were found significant statistically so the regression model was found significant $(\mathrm{P}<0.01)$. The determination coefficient $\left(\mathrm{R}^{2}\right)$ of the model was calculated as 0.142 . While the $\mathrm{pH}$ of the surface water is 7.12 in the night, it is expected that $\mathrm{pH}$ decrease 0.006 for each 1 meter increased.

Positive correlation was found between the depth and the salinity levels. The regression model of the depth and the salinity was estimated for the night values as:

$$
\text { Salinity }=38.278+(0.108) \cdot \text { Depth }
$$

The parameters in the regression model were significant statistically so the regression model was significant $(\mathrm{P}<0.01)$. The determination coefficient $\left(\mathrm{R}^{2}\right)$ of the model was calculated as 0.426 . While the salinity of the surface water is $38.278 \mathrm{ppt}$ in the night, it is expected that the salinity increase 0.108 for each 1 meter increased.

Regression equation for day at $40 \mathrm{~m}$ is:

$$
\begin{gathered}
\text { Chlorophyll } a=-204-0,814 \mathrm{~T}-16,2 \mathrm{~S}+7,6 \mathrm{pH}+0,331 \mathrm{O}_{2}+ \\
0,0137 \mathrm{C}\left(\mathrm{R}^{2}=0.64868 .4\right)
\end{gathered}
$$

Regression equation for night at $40 \mathrm{~m}$ is:

Chlorophyll $a=179-0,392 \mathrm{~T}-4,00 \mathrm{~S}-31,0 \mathrm{pH}-0,594 \mathrm{O}_{2}+$ $0,00361 \mathrm{C}\left(\mathrm{R}^{2}=0.609\right)$

\section{Discussion}

Y1lmaz et al, 1992 reported that the surface water salinity was measured approximately as $39 \mathrm{ppt}$ and the temperature was measured as $29^{\circ} \mathrm{C}$ at the study in Iskenderun bay. Polat et al., 2006 found that the surface water salinity has changed between 33.6 and $37.1 \mathrm{ppt}$, and the temperature has also changed from $15.8^{\circ} \mathrm{C}$ to $32.8^{\circ} \mathrm{C}$ 
in Iskenderun Bay. In the same region, Lakkis and Toklu, 2007 stated that the temperature was $29^{\circ} \mathrm{C}$ at the surface; the salinity was $28-38$ ppt in July-August. Terbiyık and Polat, 2012 notified that salinity was between 38.06 and $41.7 \mathrm{ppt}$, while the temperature ranged from 18.52 to $29.12{ }^{\circ} \mathrm{C}$ and $\mathrm{DO}$ ranged from $4.46+0.24 \mathrm{mg} \mathrm{L}^{-1}$ to 7.96 $+0.06 \mathrm{mg} \mathrm{L}^{-1}$, Chlorophyll $a$ varied from $0.42+0.08 \mu \mathrm{g}$ $\mathrm{L}^{-1}$ to $1.08+0.14 \mu \mathrm{g} \mathrm{L}^{-1}$ in Iskenderun bay. Terbiyık Kurt and Polat, 2014 found that salinity changed between 36.96 and $41.78 \mathrm{ppt}$, the temperature varied from 17.55 to $29.23^{\circ} \mathrm{C}$ at their study in Iskenderun Bay. Similar results were obtained in this study too. The surface water salinity was $38 \mathrm{ppt}$, the temperature approximately has been changing between 26 and $28^{\circ} \mathrm{C}$. However, the temperature decreased until $22^{\circ} \mathrm{C}$ at $40 \mathrm{~m}$.

The study area, Yumurtalik Bay was affected from the anticyclonic stream system observed at the surface water out of the bay, and also observed that cyclonic stream (Akyüz, 1957; İyiduvar, 1986). The effect of the depth on the temperature and salinity was observed during the day. During the night the effect of the depth on the temperature, salinity and chl $a$ wasobserved.

\section{Conclusions}

The fisheries activities were carried out in the region and it was known that the physical and chemical properties are important for the food chain in the aquatic environment. The estimation of the some physicochemical parameters will be support the studies about the primary and secondary productivity of the area. In addition to the insignificance of the determination coefficient $\left(\mathrm{R}^{2}\right)$ of the models for the parameters of DO and chlorophyll $a$ can be related with the streams in the area. The regression models of the depth and the temperature, salinity, light intensity and $\mathrm{pH}$ can be use for the fisheries activities in the region.

\section{References}

Akyüz EF. 1957. Observation on the İskenderun red mullet (Mullus barbatus) and its environment. Proc. Gen. Counc Med;4 305326.

Avşar D, Çiçek E. 1999. Yumurtalık Koyu'nun (Adana) Hidrografik Özelliklerinin Belirlenmesi Için Bir Ön Çalışma, X. Su Ürünleri Sempozyumu, Adana, 715-731.

Draper NR, Smith H. 1966. Applied Regression Analysis, (John Wiley and Sons Inc., NewYork) pp. 549.

Gill J. 1955. Design and Analysis of Experiments and Medical Sciences, (The Iowa State Univ. Pres) Vol 1, 2, 3 pp. 410.

Iyiduvar Ö. 1986. Hydrografic characteristics of İskenderun Bay. M. Sc. thesis, Institute of Marine Sciences, Middle East Technical University, 33731, 157p.

Lakkis S, Toklu B. 2007. Contribution to the study of zooplankton community in Iskenderun Bay (North-eastern Mediterranean).Rapp.Comm.Int Mer Medit. 38.527.

Parsons TR, Strickland JDH. 1963. Discussion of spectrophotometric determination of marine plant pigments, with revised equations for ascertaining chlorophylls and carotenoids. J. Marine Research, 21;155-163.

Polat S, Perçin Olgunoğlu M, Akiz Aka A, Koray T. 2006. Kuzeydoğu Akdeniz Kıyısal Sularında (İskenderun Körfezi) Dağılım Gösteren Potansiyel Zararlı Fitoplankton Türleri. E.Ü. Su Ürünleri Dergisi, 23, 169-172.

Terbiyik T, Polat S. 2012. Seasonal distribution of coastal mesozooplankton community in relation to the environmental factors in Iskenderun Bay (North-east Levantine, Mediterrancan Sea) Journal of the Marine Biological Association of the United Kingdom, 1-12, doi: 10.1017/SOO25315412001713.

Terbiyik T, Polat S. 2014 Characterization of the seasonal and interrannual changes in abundance of marine cladoceran species in Turkish coast of the Northeastern Levantine Basin Crustaccana, 87(7): 769-783.

Yılmaz A, Bastürk Ö, Saydam C, Ediger D, Yılmaz K, Hatipoğlu E. 1992. Eutrophication in Iskenderun Bay, North-eastern Mediterranean. Sceince of the Total Environment (Special Issue) In: Marine Coastal Eutrophication, (Eds: Vollenweider R.A., Marchetti R., Viviani R.) Elsevier, Amsterdam, 705 -717 